\title{
Short-distance sensory stimulation technique in the early diagnosis of carpal tunnel syndrome
}

\author{
Karpal tünel sendromunun erken tanısında kısa mesafeli duyu iletim tekniği \\ Betül Çevik*, Ali İhsan Baysal \\ Department of Neurology (Assist. Prof. B. Çevik, MD.), Gasiosmanpaşa University School of \\ Medicine, TR-60100 Tokat, Department of Neurology (Prof. A. İ. Baysal, MD.), Madalyon \\ Psychiatry Center, TR-06540 Ankara.
}

\begin{abstract}
Aim. Normal results obtained from nerve conduction studies do not exclude the diagnosis of carpal tunnel syndrome (CTS). We intended to increase diagnostic sensitivity of nerve conduction studies in the early stage CTS by stimulating shorter palm-wrist segment, and excluding distal region outside the entrapment site of the median nerve which is unaffected from pathologic changes. Methods. In this prospective study, 41 patients (66 hands) with clinically diagnosed CTS with normal conventional electrophysiologic examinations were stimulated with electrodes placed at $8,7,6,5,4 \mathrm{~cm}$ from the distal wrist crease (DWC) on the palm-wrist segment, and the conduction velocities, latencies, and the differential latencies (conduction delay) were compared with those of 34 patients ( 68 hands) in the control group. Results. Conduction delay recorded between $4-5,5-6,6-7,7-8 \mathrm{~cm}$. away from DWC of both groups was statistically insignificant $(\mathrm{p}>0.1)$, while the conduction velocities and the latencies obtained from the electrodes placed on 4, $5,6,7$, and $8 \mathrm{~cm}$ away from DWC differed statistically significantly between two groups $(\mathrm{p}<0.001)$. Conclusion. In electrophysiologic examinations performed to confirm the diagnosis of CTS, assessment of shorter palm-wrist segment, and stimulation of a predetermined location 4 or 5 $\mathrm{cm}$ distal to DWC are sufficient to detect a slight and localized conduction delay in the carpal tunnel. This method eliminated slowing-down effect of distal segment on normal nerve conduction velocities yielding higher degrees of (up to $92.4 \%$ ) sensitivity.
\end{abstract}

Keywords: Carpal tunnel syndrome, nerve conduction studies, palm-wrist conduction, shortdistance stimulation

\section{Özet}

Amaç. Sinir iletim çalışmalarının normal olması karpal tünel sendromu (KTS) tanısını dışlamaz. Biz bu çalışmada, erken evre KTS'de avuçiçi-bilek segmentindeki mesafeyi daha kısa tutup, median sinirin tuzaklanma bölgesi dışındaki, henüz patolojik değişikliklerden etkilenmemiş distal bölgesini çıkararak, KTS tanısında duyarlılığı artırmayı amaçladık. Yöntem. Bu prospektif çalışmada, klinik olarak KTS tanısı konan, konvansiyonel elektrofizyolojik incelemeleri normal olan 41 olguda (66 el), avuçiçi-bilek segmentinde; distal bilek çizgisinden (DBÇ) sırasıyla 8, 7, 6, $5,4 \mathrm{~cm}$ mesafelerden uyarım yapılmış, bu mesafelerdeki hız, latans ve latanslar arası farkları (iletim gecikmesi), kontrol grubundaki 34 olgunun (68 el) verileriyle karş1laştırılmıştır. Bulgular. 4-5, 5-6, 6-7, 7-8. cm.' ler arası latans fark1 (iletim gecikmesi) her iki grup arasında istatistiksel olarak anlamsız olup ( $>0.1) ; 4,5,6,7,8$. cm.' lerdeki hız, latans değerleri her iki grup arasında istatistiksel olarak anlamlı bulunmuştur $(p<0.001)$. Sonuç. KTS tanısını doğrulamak için yapılan elektrofizyolojik incelemede, avuçiçi-bilek segmentinde, mesafenin daha kısa tutulup, uyarımın DBÇ'nin 4 ve/veya $5 \mathrm{~cm}$ distalinden yapılması, karpal tüneldeki hafif ve lokalize iletim gecikmesini tespit etmede yeterlidir. İletim hızı normal olan distal segmentin hafifletici etkisinin ortadan kalkmasıyla duyarlılık \%92,4'e yükselmiştir.

Anahtar sözcükler: Karpal tünel sendromu, sinir ileti çalışmaları, avuçiçi-bilek iletimi, kısa mesafe stimulasyon

Geliş tarihi/Received: September 05, 2013; Kabul tarihi/Accepted: December 03, 2013 


\section{*Corresponding author:}

Dr. Betül Çevik, Nöroloji Anabilim Dalı, Gaziosmanpaşa Tıp Fakültesi, TR-60100 Tokat. E-mail: cevikbetul78@hotmail.com

\section{Introduction}

Carpal tunnel syndrome (CTS) is the most frequently seen peripheral nerve entrapment neuropathy [1]. CTS is common in women and occurs most often in the fifth and sixth decades $[1,2]$. The prevalence varies between $0.6 \%$ to $2.1 \%$ in males and $3.0 \%$ to $5.8 \%$ in females [3-5].

Because of its frequent occurrence, disturbing symptoms, and potentially irreversible nerve damage (if left untreated), early diagnosis, and treatment carry utmost importance. The diagnosis of CTS involves a combination of a detailed clinical history, accurate physical examination and, where appropriate, electrodiagnostic studies (EDSs) [6, 7]. Median sensory and motor nerve conduction studies (NCSs) are valid and reproducible clinical laboratory studies that confirm a clinical diagnosis of CTS in patients with a high degree of sensitivity and specificity [8]. In approximately $95 \%$ of the patients with established clinical diagnoses of CTS based primarily on their signs, and symptoms, NCSs have yielded positive results [1]. Nonetheless, as EDSs do not have definite accuracy, in a portion of patients (about 10-20\%) complaining of the typical signs and symptoms of CTS, EDS results are negative $[7,9,10]$. Therefore, normal results obtained from NCSs do not exclude the diagnosis of CTS.

The aim of this study was to increase the diagnostic sensitivity of nerve NCSs in the early stage CTS by stimulating shorter palm-wrist segment (PWS), and excluding distal region outside the entrapment site of the $\mathrm{MN}$ which is unaffected from pathologic changes.

\section{Materials and methods}

\section{Control subjects}

Healthy control subjects consisted of volunteers and hospital staff. A screening medical history, detailed physical, and neurological examinations excluded individuals with CTS, peripheral neuropathy or relevant systemic conditions such as diabetes mellitus, renal impairment or exposure to toxins or drugs. Control group consisted of 7 male, and 27 female patients (68 hands). The control subjects were between 22-50 (mean 37,78 $\pm 7,38$ ) years of age. Two hands were examined in each of the normal subjects. Conventional NCSs and orthodromik inching technique (IT) was performed in all of these volunteers, and those with normal conventional NCSs findings were enrolled as the control group [11]. Normal limits were derived by calculating the mean \pm 2 standard deviations from the data of the controls.

\section{Patients}

In this prospective case control study, during a 1-year period, we enrolled 41 (37 females (59 hands), and 4 males ( 7 hands) consecutive patients referred to our electrophysiology laboratory who were clinically diagnosed as CTS with normal conventional electrophysiologic test findings. The patients were between 23-50 (mean 40,08 $\pm 7,25$ ) years of age. Patients with symptoms lasting at least 3 months were enrolled in the study. In all patients, the frequency and distribution of paresthesia were typical of CTS. Patients with CTS enrolled in this study were diagnosed clinically on the basis of the presence of following primary symptoms: (1) intermittent symptoms of numbness, tingling, pain, or paresthesia limited to the MN distribution; (2) precipitation of these symptoms by repetitive hand activities and relieved by resting, rubbing, and shaking the hand; (3) nocturnal awakening by such sensory symptoms [12]. Only patients with idiopathic CTS (with absent etiologic clues) were enrolled. In addition, patients with a fixed or continuous sensory complaint (numbness or pain) or with an abnormal pinprick sensation 
over the median nerve $(\mathrm{MN})$ distribution and those with abductor pollicis brevis muscle wasting or weakness on neurologic examination were excluded. If one symptomatic hand had abnormal NCSs results and the other symptomatic hand had normal NCSs results, the hand with normal NCSs results was enrolled in the patient group.

In patients with clinically diagnosed CTS, conventional conduction studies were performed, and those with negative results were included in the patient group, and sensory orthodomic IT was applied on PWS. Motor and sensory conductions of the ulnar nerve (UN) were also analyzed in the suspected limb in all patients to exclude a probable polyneuropathy associated with CTS.

This study was performed in accordance with the Declaration of Helsinki. After a detailed explanation of the study, all subjects were provided written informed consent.

\section{Electrophysiologic studies}

Electrophysiologic studies of all patients were performed by the same author (Betül Çevik) with a Neuropack $\varepsilon$ (Nihon Kohden) electromyography machine. Skin temperature on the hand was measured before EDSs and maintained at or above $32^{\circ} \mathrm{C}$ during the NCSs by using an infrared lamp [13]. All studies were performed when the patients were in supine position.

\section{1) Conventional motor $\mathrm{NCSs}$}

In the motor NCSs, during the stimulating of the median and ulnar nerves, the recording electrodes were placed over the belly of the abductor pollicis brevis and abductor digiti minimi muscles, respectively. Reference electrodes were placed over the distal tendinous insertion. Distal stimulations of the nerves were performed at the wrist and $5 \mathrm{~cm}$ proximal to the active electrode, and proximal stimulations were carried out for the MN at the elbow crease, on the ulnar side of the pulsating brachial artery, and for the UN at the elbow sulcus. The motor latencies were measured from the stimulus onset to the beginning of the initial deflection of the compound muscle action potentials (CMAPs), and the amplitudes were measured from peak to peak.

For MN, distal latency greater than 3,8 ms, nerve conduction velocity (NCV) below 49,7 $\mathrm{m} / \mathrm{s}$, and CMAP amplitude lower than $4,3 \mathrm{mV}$ were considered to be abnormal. For UN, distal latency greater than $3,3 \mathrm{~ms}$, NCV below 49,9 m/s, CMAP lower than $7 \mathrm{mV}$ were considered to be abnormal. Normal F-wave latencies of the MN and UN were below 32 ms.

\section{2) Conventional sensory and mixed NCSs}

The orthodromic method, also used in routine laboratory studies, was preferred in sensory NCSs because the antidromic method is thought to have the disadvantage of an accompanying motor response (because motor fibers are also stimulated), which may distort the small compound nerve action potential.

To assess sensory NCVs of the MN and UN, the stimulating electrodes were placed over the digit I, digit II, digit III, and digit V, with the active stimulating electrode over the proximal phalanx and the reference electrode over the middle phalanx. Stimulation of the MN was also performed in the palm between the second and the third metacarpal heads, with a maximum $8 \mathrm{~cm}$ conduction distance. The recording silver disc electrodes, of which the active ones were located distally, were placed on the volar side of the wrist. The sensory latencies were measured from the negative peak of the the sensory nerve action potential (SNAP), and the amplitudes were measured from peak to peak.

The lower limits of normal for the MN sensory NCVs in our laboratory were $32,9 \mathrm{~m} / \mathrm{s}$ for digit I, 39,4 m/s for digit II, 39,6 m/s for digit III, and $35,2 \mathrm{~m} / \mathrm{s}$ for the PWS. UN sensory NCV for digit V was considered to be normal if it was above $37,3 \mathrm{~m} / \mathrm{s}$. 


\section{3) Application of orthodromic inching technique on palm-wrist segment}

Orthodromic IT was applied on sensory fibers of MN on PWS. The patient was informed about the technique to be performed. Active surface electrode was placed on the distal wrist crease (DWC). In the beginning, the ground electrode was situated between the stimulating and the recording electrodes. While forearm, wrist, and palms were in supine position, a line was drawn from DWC to the digit III, and 4, 5, 6., 7, and $8 \mathrm{~cm}$ distal to the DWC were marked. To minimize the error of marking the distance points measured from the wrist, the digit III was chosen. Supramaximal stimulations were applied on 8, 7, 6,5 , and $4 \mathrm{~cm}$ distal to the DWC and sensory NCVs, sensory latencies, differential latencies (conduction delays) between four segments $(4-5,5-6,6-7$, and 7-8 cm, respectively) were examined. Measurements of the sensory latencies were recorded from the negative peak of the SNAPs.

The results of the IT of the patients who were clinically diagnosed as CTS were compared with normal values obtained from the control group to determine the group with abnormal electrophysiologic findings.

\section{Statistical analysis}

Statistical analysis was performed by statistical software package SPSS for Windows (release 9.0.; SPSS Inc., USA). Comparisons of variables between the patient and the control groups were made using chi-square analysis for categorical variables, Student's sample $t$ test for normally distributed continuous variables. A $p$ value of $<0.05$ were considered as statistically significant.

\section{Results}

In the patient group, the right hands of three patients had mild, and the right hand of one patient and the left hand of one patient had moderate degrees of CTS, the other hands of the symptomatic patients with normal conventional EDSs results were included in the study.

Any statistically significant difference was not found between the mean ages and sex of the patient and the control groups. The mean sensory NCVs detected in the patient group at $4,5,6,7$, and 8 . cm from the DWC were statistically significantly slower than those of the control group. Similarly, sensory latencies measured for the above-mentioned distances were longer relative to those of the control group (Table 1).

Table 1. Comparison of the median sensory NCVs, latencies, and the latency differences of the patient and the control groups at 4, 5, 6, 7, 8. cm distal to DWC.

\begin{tabular}{|c|c|c|c|}
\hline & $\begin{array}{l}\text { Patients } \\
\text { Mean } \pm \text { SD }(n=66)\end{array}$ & $\begin{array}{l}\text { Controls } \\
\text { Mean } \pm \text { SD }(n=68)\end{array}$ & p value* \\
\hline Velocity at $4 . \mathrm{cm}(\mathrm{m} / \mathrm{s})$ & $30,07 \pm 1,95$ & $36,26 \pm 1,54$ & $<0,001$ \\
\hline Velocity at $5 . \mathrm{cm}(\mathrm{m} / \mathrm{s})$ & $34,76 \pm 1,76$ & $40,14 \pm 1,97$ & $<0,001$ \\
\hline Velocity at $6 . \mathrm{cm}(\mathrm{m} / \mathrm{s})$ & $37,46 \pm 1,69$ & $42,52 \pm 2,25$ & $<0,001$ \\
\hline Velocity at $7 . \mathrm{cm}(\mathrm{m} / \mathrm{s})$ & $39,27 \pm 1,76$ & $44,10 \pm 2,48$ & $<0,001$ \\
\hline Velocity at $8 . \mathrm{cm}(\mathrm{m} / \mathrm{s})$ & $40,66 \pm 1,87$ & $45,47 \pm 2,23$ & $<0,001$ \\
\hline Latency at $4 . \mathrm{cm}(\mathrm{ms})$ & $1,32 \pm 0,07$ & $1,11 \pm 0,04$ & $<0,001$ \\
\hline Latency at $5 . \mathrm{cm}(\mathrm{ms})$ & $1,44 \pm 0,08$ & $1,25 \pm 0,06$ & $<0,001$ \\
\hline Latency at $6 . \mathrm{cm}(\mathrm{ms})$ & $1,60 \pm 0,08$ & $1,41 \pm 0,07$ & $<0,001$ \\
\hline Latency at $7 . \mathrm{cm}(\mathrm{ms})$ & $1,78 \pm 0,08$ & $1,59 \pm 0,09$ & $<0,001$ \\
\hline Latency at $8 . \mathrm{cm}(\mathrm{ms})$ & $1,97 \pm 0,10$ & $1,76 \pm 0,09$ & $<0,001$ \\
\hline Latency difference at $4-5 . \mathrm{cm}(\mathrm{ms})$ & $0,15 \pm 0,02$ & $0,14 \pm 0,04$ & $>0,05$ \\
\hline Latency difference at 5-6. $\mathrm{cm}(\mathrm{ms})$ & $0,16 \pm 0,03$ & $0,17 \pm 0,03$ & $>0,05$ \\
\hline Latency difference at 6-7. $\mathrm{cm}(\mathrm{ms})$ & $0,18 \pm 0,03$ & $0,18 \pm 0,03$ & $>0,05$ \\
\hline Latency difference at 7-8. $\mathrm{cm}(\mathrm{ms})$ & $0,18 \pm 0,03$ & $0,17 \pm 0,03$ & $>0,05$ \\
\hline
\end{tabular}


In this study, no statistically significant difference was detected between the patient and the control groups regarding the differential latencies (conduction delays) of the median sensory NCVs between four subsegments, i.e. 4-5, 5-6, 6-7, and 7-8 cm (Table 1). In the sensory NCSs of PWS using IT performed on 66 hands with clinically conceived CTS, positive result was obtained in 61 hands yielding a 92,4\% test sensitivity.

In present study, the female/male ratio of patients with CTS was found to be 9,5/1. A statistically significant regarding the distal motor latencies of $\mathrm{MN}$ was found between the patient $(2,63 \pm 0,35 \mathrm{~ms})$ and the control $(2,35 \pm 0,29 \mathrm{~ms})$ groups $(\mathrm{p}<0.001)$. When the $\mathrm{F}$ wave latencies of $\mathrm{MN}$ were compared between the patient and the control groups, no statistically significant difference was found $(\mathrm{p}=0,69)$.

None of the subjects included in the patient or the control groups had any abnormality of $\mathrm{UN}$ sensory conduction velocity, UN and MN F wave latencies or MN mixed or motor NCVs through wrist-elbow segment.

\section{Discussion}

Symptoms and clinical findings alone are generally insufficient for evaluate the degree of nerve entrapment and functional status [2]. Approximatelly 10-15\% of subjects with classic symptoms of CTS, EDSs are negative [7]. For this reason, NCSs may confirm, but not rule out, the diagnosis of CTS. It is postulated that the principal sensory fibres injured in compressive neuropathies are small and cannot be reliably evaluated with EDSs. In fact, EDSs are more a diagnostic tool to evaluate large myelinated nerve fibres rather than small unmyelinated ones [14]. Very mild lesions with no detectable electrophysiologic alterations can occur. This may be explained by conduction anomalies of $\mathrm{MN}$ are focal and at least in the early stages of the disease, limited to the proximal segment that lies in the carpal tunnel (CT). For this reason, relatively more rapid conducting in the distal segment may mask mild slowing of conduction in the proximal segment. Hence, PWS study (which evaluate the involved segment of MN) are more sensitive for detecting mild abnormalities [1,9].

In cases without any demonstrated abnormal findings, despite identification of typical CTS symptoms, distal segment with faster conductivity might mask slightly NCV through proximal segment. Therefore, segmental studies have a higher sensitivity in the assessment of mild abnormalities in the affected MN segment [9].

When all of these data were taken into consideration, we aimed to increase the sensitivity of the IT for the diagnosis of CTS. For this purpose, we excluded the distal region outside the entrapment region of $\mathrm{MN}$ inside the $\mathrm{CT}$, which is unaffected from pathological changes and shortened the PWS to be stimulated. At the end of the study, when the data obtained from the control and the patient groups were compared, a statistically significant difference was observed regarding the MN NCVs and the latencies recorded at 4., 5., 6., 7. and $8 . \mathrm{cm}$ in the PWS. None of the subjects included in the patient group had any conduction delay in any segments examined.

Since IT evaluates nerve conductivity in every centimeter of the relevant segment, in patients where other tests yield normal results, it is more advantageous in providing accurate information about the exact localization of the site of conduction delay [15]. The sensitivity of orthodromic IT has found to be higher than antidromic technique, though the latter technique demonstrates higher compound nerve action potential amplitudes [16].

Studies using longer segments demonstrate lesser degrees of sensitivity. Indeed inclusion of unaffected segments in a stimulation protocol attenuates the effect of conduction delay in the lesion site $[9,15]$. Assuming that normal conduction velocity of a nerve impulse is $0,2 \mathrm{~ms} / \mathrm{cm}(50 \mathrm{~m} / \mathrm{s})$, and slows down to $0,5 \mathrm{~ms} / \mathrm{cm}(20 \mathrm{~m} / \mathrm{s})$ while passing through a $1 \mathrm{~cm}$ of demyelinated segment, an increase of $0,3 \mathrm{~ms}$ in a $10-\mathrm{cm}$ segment will cause a $15 \%$ variation in latency. This degree of variation might remain within normal limits. 
However, if measurement is performed on a $1 \mathrm{~cm}$ segment, the same latency increase $(0,3$ ms) represents a $150 \%$ variation in latency, which is extremely higher than normal limits of variation. This extent of variation, quite higher than normal variation limits, might detect a focal abnormality in a chronically compressed nerve even before occurrence of any loss in the amplitude or a major change in the configuration of SNAP [15]. In this study, increasing in sensitivity by shortening PWS might be explained by this mathematical fact.

IT has the advantage of localising focal abnormalities of the MN along the CT. Although inching is a reliable method, because multiple sites are stimulated, it has the disadvantages of being time-consuming and uncomfortable when compared with other electrophysiologic tests used for the identification of mild MN lesions. In addition, this technique can be difficult to record because of stimulation artifact [7, 17]. Therefore, in place of our technique, in patients with CTS symptomatology but with normal conventional EDSs findings, it is sufficient to stimulate MN in PWS at a $6 \mathrm{~cm}$ shorter distance (from 4. and 5. cm) distal to DWC to measure NCVs. Although the technique performed in this study could not yield $100 \%$ sensitivity, its shorter application time, and practicability might be considered as an advantage in routine usage.

In a previous study which examined motor NCVs of $23 \mathrm{MNs}$ intraoperatively, found that NCVs were abnormal when MNs were stimulated 1 to $2 \mathrm{~cm}$ distal to the beginning of the CT in 15 MNs [18]. In an another study using sensory IT, abnormal results were found between $1-2 \mathrm{~cm}$. from the DWC in $57 \%$ and between $2-3 \mathrm{~cm}$ in $21 \%$ of cases [19]. These findings are in sharp contrast to the Kimura's study. Kimura used the antidromic sensory NCV study by stimulation of the nonexposed nerve along the CT in $1 \mathrm{~cm}$ increments. He localized the most abnormal conduction to the 2 to $4 \mathrm{~cm}$ distal to the origin of the transverse carpal ligament (TCL) in 52\% of 91 affected nerves [20]. Using Kimura's technique, Nathan et al. [21] also localized the most common site of compression to the segment of 3 to $4 \mathrm{~cm}$ distal to the DWC. Seror determined the typical location of impaired conduction at 3-4 $\mathrm{cm}$ or 2-4 $\mathrm{cm}$ distal to the DWC, when he applied sensory orthodromic IT at 1 or $2 \mathrm{~cm}$ intervals, respectively [17, 22]. All these findings have demonstrated that $\mathrm{MN}$ was compressed inside the CT approximately 2 to $4 \mathrm{~cm}$ distal to the DWC. Anatomic studies also localized this region distal end of the TCL [15]. Also in this study, the probability of detecting an abnormality increased as we approached entrapment site within CT during NCSs.

Seror [17] reported that the sensitivity of orthodromic IT was $96 \%$. In this study, the sensitivity of our technique was $92,4 \%$. The reason for higher sensitivity of the Seror's technique might be due to the assessment of all segments in the CT, which enabled realization of short-segment conduction studies on the entrapment site. However, in our study, when a short-nerve segment conduction study was performed by stimulating $\mathrm{MN}$ at the distal end of the TCL, a location near the entrapment site within CT, we obtained higher sensitivity than the PWS sensory NCSs, where 6-8 cm long segment is evaluated. However since we could not apply IT exactly on the mild and localized entrapment site, sensitivity of our technique is inferior to that of Seror's technique.

In the orthodromic and/or antidromic IT performed by investigators, they could not detect any conduction delay between segments $4 \mathrm{~cm}$ distal to the DWC $[15,17,20,21]$, because these segments were not exactly in CT, ie. entrapment site. Accordingly, we could not detect any conduction delay at segments 4-5, 5-6, 6-7, 7-8 cm distal to the DWC.

Although the distal motor latencies in the patient group remained below the lower limit of normal $(3,8 \mathrm{~ms})$, a statistically significant difference was found when compared with those of the control group.

$\mathrm{F}$ wave latencies of the $\mathrm{MN}$ were detected to be normal in all of the participants. $\mathrm{F}$ wave latencies abnormalities are encountered in severe cases of CTS as evidenced both clinically and electrophysiologically [17]. Since our patients demonstrated abnormalities 
only in short segmental tests which correspond to Stage 1 (minimal CTS) in the electrophysiologic staging of Italian CTS study group [23], lack of F wave abnormality is in accordance with the literature findings.

This study demonstrated that, in electrophysiologic studies performed to confirm the diagnosis of CTS, assessment of shorter PWS, and stimulation of this segment 4 and/or 5 $\mathrm{cm}$ distal to the DWC are sufficient to detect a slight and localized delay in the CT. Also, this study revealed an increase in the degree of sensitivity up to $92,4 \%$ after eliminating the weakening effect of distal segment on NCV.

\section{References}

1. Oh SJ. Clinical electromyograhy nerve conduction studies, in 3rd ed. Philadelphia: Lippincott Williams \& Wilkins; 2003.

2. Patijn J, Vallejo R, Janssen M, Huygen F, Lataster A, van Kleef M, Mekhail N. Carpal tunnel syndrome. Pain Pract 2011; 11: 297-301.

3. Atroshi I, Gummesson C, Johnsson R, Ornstein E, Ranstam J, Roeén I. Prevalence of carpal tunnel syndrome in a general population. JAMA 1999; 282: 153-8.

4. de Krom MC, Knipschild PG, Kester AD, Thijs CT, Boekkooi PF, Spaans F. Carpal tunnel syndrome: prevalence in the general population. J Clin Epidemiol 1992; 45: 373-6.

5. Stevens JC, Sun S, Beard CM, O'Fallon WM, Kurland LT. Carpal tunnel syndrome in Rochester, Minnesota, 1961 to 1980. Neurology 1988; 38: 134-8.

6. Rempel D, Evanoff B, Amadio PC, de Krom M, Franklin G, Franzblau A, Gray R, Gerr F, Hagberg M, Hales T, Katz JN, Pransky G. Consensus criteria for the classification of carpal tunnel syndrome in epidemiologic studies. Am J Public Health 1998; 88: 1447-51.

7. Werner RA, Andary M. Electrodiagnostic evaluation of carpal tunnel syndrome. Muscle Nerve 2011; 44: 597-607.

8. Jablecki CK, Andary MT, So YT, Wilkins DE, Williams FH. Literature review of the usefulness of nerve conduction studies and electromyography for the evaluation of patients with carpal tunnel syndrome. AAEM Quality Assurance Committee. Muscle Nerve 1993; 16: 1392-414.

9. Padua L, Giannini F, Girlanda P, Insola A, Luchetti R, Lo Monaco M, Padua R, Uncini A, Tonali P. Usefulness of segmental and comparative tests in the electrodiagnosis of carpal tunnel syndrome: the Italian multicenter study. Italian CTS Study Group. Ital J Neurol Sci 1999; 20: 315-20.

10. Rahmani M, Ghasemi Esfe AR, Vaziri-Bozorg SM, Mazloumi M, Khalilzadeh O, Kahnouji $\mathrm{H}$. The ultrasonographic correlates of carpal tunnel syndrome in patients with normal electrodiagnostic tests. Radiol Med 2011; 116: 489-96.

11. Alfonso C, Jann S, Massa R, Torreggiani A. Diagnosis, treatment and follow-up of the carpal tunnel syndrome: a review. Neurol Sci 2010; 31: 243-52.

12. Practice parameter for carpal tunnel syndrome (summary statement). Report of the quality standards subcommittee of the american academy of neurology. Neurology 1993; 43: 2406-9.

13. Jablecki CK, Andary MT, Floeter MK, Miller RG, Quartly CA, Vennix MJ, Wilson JR; American Association of Electrodiagnostic Medicine; American Academy of Neurology; American Academy of Physical Medicine and Rehabilitation. Practice parameter: Electrodiagnostic studies in carpal tunnel syndrome. Report of the American Association of Electrodiagnostic Medicine, American Academy of Neurology, and the American Academy of Physical Medicine and Rehabilitation. Neurology 2002; 58: 1589-92.

14. Nora DB, Becker J, Ehlers JA, Gomes I. Clinical features of 1039 patients with neurophysiological diagnosis of carpal tunnel syndrome. Clin Neurol Neurosurg 2004; 107: 64-9. 
15. Kang YK, Kim DH, Lee SH, Hwang M, Han MS. Tenelectrodes: a new stimulator for inching technique in the diagnosis of carpal tunnel syndrome. Yonsei Med J 2003; 44: 479-84.

16. Seror P. Comparative diagnostic sensitivities of orthodromic or antidromic sensory inching test in mild carpal tunnel syndrome. Arch Phyl Med Rehabil 2000; 81: 442-6.

17. Seror P. Orthodromic inching test in mild carpal tunnel syndrome. Muscle Nerve 1998; 21: 1206-8.

18. Brown WF, Ferguson GG, Jones MW, Yates SK. The location of conduction abnormalities in human entrapment neuropathies. Can J Neurol Sci 1976; 3: 11122.

19. Luchetti R, Schoenhuber R, Alfarano M, Montagna G, Pederzini L, Soragni O. Neurophysiological assessment of the early phases of carpal tunnel syndrome with the inching technique before and during operation. J Hand Surg Br 1991; 16: 415-9.

20. Kimura J. The carpal tunnel syndrome: localization of conduction abnormalities within the distal segment of the median nerve. Brain 1979; 102: 619-35.

21. Nathan PA, Srinivasan H, Doyle LS, Meadows KD. Location of impaired sensory conduction of the median nerve in carpal tunnel syndrome. J Hand Surg Br 1990; 15: 89-92.

22. Seror P. Simplified orthodromic inching test in mild carpal tunnel syndrome. Muscle Nerve 2001; 24: 1595-600.

23. Padua L, Padua R, LoMonaco M, Romanini E, Tonali P. Italian multicentre study of carpal tunnel syndrome: study design. Italian CTS Study Group. Ital J Neurol Sci 1998; 19: 285-9. 